\title{
Establishing a Primary Care Performance Measurement Framework for Ontario
}

\section{Mise en place d'un cadre pour la mesure du rendement des soins primaires en Ontario}

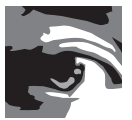 \\ WISSAM HAJ-ALI, BSCN, MPH, CPH \\ Health Quality Ontario \\ Institute of Health Policy Management and Evaluation, University of Toronto \\ Toronto, $\mathrm{ON}$ \\ BRIAN HUTCHISON, BA, MD, MSC, CCFP, FCFP \\ Departments of Family Medicine and Health Research Methods, Evidence and Impact \\ Centre for Health Economics and Policy Analysis \\ McMaster University \\ Hamilton, $\mathrm{ON}$
}

On behalf of the Primary Care Performance Measurement Steering Committee

\begin{abstract}
A systematic approach to Primary Care Performance Measurement is needed to provide useful information on a regular basis to inform planning, management and quality improvement at both the practice and system levels. Based on an environmental scan, a summit of primary care stakeholders and a stakeholder survey and supported by Measures and Technical Working Groups, the Ontario Primary Care Performance Measurement Steering Committee, representing 20 stakeholder organizations, identified system- and practice-level measurement priorities and related specific performance measures across nine domains of primary care performance. This initiative addressed measures' selection and technical specification. It did not include data collection. Lessons learned in Ontario can assist other jurisdictions developing frameworks for monitoring and reporting on primary care performance. Cross-country alignment could lead to a coordinated approach to measure and target areas for primary care performance improvement in Canada.
\end{abstract}




\section{Résumé}

Une approche systématique pour la mesure du rendement des soins primaires est nécessaire afin d'obtenir, sur une base régulière, de l'information utile à la planification, à la gestion et à l'amélioration de la qualité, et ce, tant au niveau de la pratique que du système. En se fondant sur une analyse du contexte, sur un sommet réunissant les intervenants de première ligne ainsi que sur un sondage auprès des intervenants, et comptant sur l'appui des groupes de travail technique et sur les mesures, le Comité directeur pour la mesure du rendement des soins primaires en Ontario, qui représente 20 organisations clés, a identifié les priorités de mesures aux niveaux du système et de la pratique ainsi que des mesures connexes dans neuf domaines du rendement des soins primaires. Cette initiative porte sur la sélection et la spécificité technique des mesures. Elle ne comporte pas de collecte de données. Les leçons retenues en Ontario peuvent aider d'autres juridictions à développer des cadres de travail pour le suivi et la production de rapports sur le rendement des soins primaires. Un alignement à travers le pays pourrait mener à une approche coordonnée pour mesurer et viser les secteurs pour l'amélioration du rendement des soins primaires au Canada.

\section{Introduction}

A strong primary care system is the backbone of a high-performing health system. For over a decade, Ontario has focused on strengthening primary care delivery. However, the province lacks a coordinated and comprehensive approach to collect, analyze and report data on the performance of primary care at either the practice or system level. At both levels, the paucity of regular feedback on key aspects of performance hinders efforts to identify opportunities for improvement and track the effect of improvement initiatives. At the system level, the meagre information available on primary care performance makes it difficult to monitor and evaluate the effectiveness of policy changes and investments.

In recent years, clinicians, managers and policy makers have increasingly recognized the need for systematic, ongoing feedback on primary care performance. The limited comparative data available on primary care performance at the provincial level - mainly from the Commonwealth Fund International Health Policy Surveys of primary care physicians and the public - indicate that Ontario's primary care performance compares favourably with other provinces, but lags behind international peers, particularly in timely access to care and primary care infrastructure (e.g., primary care teams, electronic medical record [EMR] systems and processes for performance measurement and improvement) (Aggarwal and Hutchison 2012; CIHI 2015, 2016; Hutchison 2013, 2014; Hutchison and Glazier 2013; Hutchison et al. 2011; Marchildon and Hutchison 2016; Osborn et al. 2014, 2015; Strumpf et al. 2012). Individual primary care practices and organizations have had little access to information on their performance, usually restricted to data they collect and analyze themselves. However, most lack the capacity to generate their own performance data. 
A number of primary care measurement frameworks have been developed in Canada in recent years, for example, those of Accreditation Canada (n.d.), CIHI (2012), Haggerty and Martin (2005), Haggerty et al. (2007), Hogg et al. (2008), Levesque et al. (2011), Watson et al. (2004). Pan-Canadian and provincial/territorial results for a 16-measure subset of CIHI's 51 primary healthcare indicators have recently been reported (CIHI 2016). Most of the proposed frameworks have been applied on a limited basis, often in a research context. None has been used to report on a province-wide basis on primary care performance at either the organization or system level.

The identification of the need for an overarching framework for strengthening primary care in Ontario can be traced to the 2010 McMaster Health Forum, Supporting Quality Improvement in Primary Health Care in Ontario (Lavis 2010). The Forum participants recommended that a planning group, including representatives of the funder and regulator of health services in Ontario (the Ministry of Health and Long-Term Care [MOHLTC]), and professional associations related to primary care (Ontario Medical Association, Registered Nurses' Association of Ontario, Association of Ontario Health Centres, Ontario College of Family Physicians) develop a strategy for strengthening primary healthcare in Ontario.

In response, the MOHLTC established and chaired the Primary Healthcare Planning Group. The group had a mandate to: (a) draft and build consensus on a strategy for strengthening primary care in Ontario; and (b) plan a meeting where a broad-based group of stakeholders would discuss and finalize the strategy (Ontario MOHLTC 2011). In its final report, the Primary Healthcare Planning Group recommended that "a Working Group be established under the auspices of Health Quality Ontario (HQO) to design a performance measurement framework including indicators to examine how the primary care system is performing against its goals and objectives at the practice, local, regional and provincial levels".

Beginning in 2012, organizations representing patients and family caregivers, primary care providers, data holders, researchers, managers and policy makers from across Ontario have worked collaboratively to develop a structured approach to measuring primary care performance that can inform decision-making at the practice and system levels. These efforts became the Primary Care Performance Measurement (PCPM) initiative. The initiative was intended as a practical, context-specific exercise to develop an approach to performance measurement that would meet the needs of key primary care stakeholders in Ontario: patients, caregivers, providers, managers, policy makers and the public. It was not designed to develop, refine or validate a conceptual framework for understanding and measuring primary care performance or to establish a generalizable set of performance measures. In this paper, we describe and reflect on the process that Ontario used to develop such an approach to PCPM.

\section{Methods}

\section{Establishing the PCPM framework}

On November 21, 2012, HQO and the Canadian Institute for Health Information (CIHI), in collaboration with their partners (the MOHLTC, Cancer Care Ontario [CCO], the Institute 
for Clinical Evaluative Sciences [ICES], eHealth Ontario and Local Health Integration Networks [LHIN]), co-sponsored an Ontario PCPM Summit in Toronto. The Summit was an invitational meeting of senior leaders from key primary care data partners and information users in Ontario. Its purpose was to start laying the foundation for PCPM in Ontario.

To support the Summit, HQO conducted an environmental scan, which examined the current state of PCPM in Ontario, across Canada and internationally. The scan provided a snapshot of existing and recently completed projects that addressed the measurement of performance in primary care settings. The scan included:

- A comprehensive literature review, with an electronic search of MEDLINE ${ }^{\circledast}$, CINAHL, EBSCO Information Services and Google Scholar databases, using the keywords: "performance measurement," "performance standards," "conceptual framework," "outcome and process assessment," "quality indicators," "evaluation of primary care" and "design and performance measurement."

- A review of grey literature.

- Contacts with organizations throughout Ontario and Canada that HQO knew were doing relevant research or developing performance measurement frameworks for primary care.

The environmental scan identified 19 performance measurement frameworks, initiatives and data sources, and summarized them in a matrix (CIHI 2013; HQO 2013a). HQO used these findings to identify primary care domains that could form the basis for an overarching framework and to select potential measurement priorities (aspects of primary care performance that are valuable to measure at the practice and system level) for each domain. Our goal was not to identify the most comprehensive or rigorous of the existing frameworks, but to select a framework around which potential performance measures could best be organized and presented for consideration by participating stakeholders. Accordingly, we selected HQO's Nine Attributes of a High Performing Health Care System Framework as the most appropriate framework for examining primary care performance in Ontario, in part because the framework was already being used in HQO's public reporting on health system performance and was therefore familiar to many stakeholders. In addition, in its 2011 report, the Primary Healthcare Planning Group recommended it (together with the Triple Aim) as the basis for a primary care measurement framework for Ontario.

The Nine Attributes align with the Triple Aim Framework of the Institute for Health Care Improvement (IHI) and six of the attributes correspond to the Six Aims for Improvement of a Health Care System proposed by the Institute of Medicine (IOM) in its ground-breaking report, Crossing the Quality Chasm: A New Health System for the 21st Century (IHI n.d.; IOM 2001) (Table 1). Because we wished to focus on primary care performance (i.e., outcomes of care and processes linked to outcomes, rather than the structure and organization of primary care), we initially excluded the HQO domain of appropriate resources. However, stakeholders were insistent that it be included on the grounds that primary care performance is contingent on the availability of needed resources. 
TABLE 1. HQO's Nine Attributes, IOM's Six Aims for Improvement and IHI's Triple Aim

\begin{tabular}{|c|c|c|c|}
\hline \multirow[b]{2}{*}{$\begin{array}{l}\text { Nine Attributes (HQO)/Six Aims for } \\
\text { Improvement (IOM) }\end{array}$} & \multicolumn{3}{|l|}{ Triple Aim (IHI) } \\
\hline & $\begin{array}{l}\text { Population health } \\
\text { (better health) }\end{array}$ & $\begin{array}{l}\text { Patient experience } \\
\text { (better care) }\end{array}$ & $\begin{array}{l}\text { Per capita health cost } \\
\text { (better value) }\end{array}$ \\
\hline Access*/timeliness $^{\S}$ & $x$ & $x$ & $x$ \\
\hline Integration* & & $x$ & $x$ \\
\hline Efficiency*§ & & & $x$ \\
\hline Effectiveness* $* \xi$ & $x$ & $x$ & $x$ \\
\hline Focus on population health* & $x$ & $x$ & \\
\hline Safety粌 & & $x$ & $x$ \\
\hline Patient-centredness*/person-centredness ${ }^{\S}$ & & $x$ & \\
\hline Appropriate resources* & & & $x$ \\
\hline Equity*\$ & $x$ & $x$ & \\
\hline
\end{tabular}

$\mathrm{HQO}=$ Health Quality Ontario; $I \mathrm{H} I=$ Institute for Health Care Improvement; IOM = Institute of Medicine. *HQO. ${ }^{5} \mid \mathrm{OM}$. Source: Adapted from Kates et al. (2012).

The Steering Committee for the Summit established the following criteria (weighted equally) to shortlist a set of measurement priorities for the Summit participants to consider:

1. The information is valuable to have on a regular basis for one or more purposes (e.g., service planning, management or quality improvement) at the practice and/or system (community, regional or provincial) levels.

2. There is a potential for comparisons of performance across practices, organizations, communities, regions, provinces/territories and/or countries.

3. The aspect of primary care performance is linked in evidence to one or more components of the IHI's Triple Aim:

- Improving the patient experience of care (better care).

- Improving population health (better health).

+ Reducing/controlling the per-capita cost of healthcare (better value).

To facilitate the Summit participants' discussions and priority setting, the Steering Committee prepared and distributed to participants a worksheet of 60 potential measurement priorities and other background materials before the meeting. The committee encouraged participants to share the information and consult widely within their organizations and with their stakeholders.

In total, 61 senior leaders attended the Summit. Following facilitated discussion, they voted for their highest performance measurement priorities, keeping in mind the following question: What aspects of primary care performance would be the most valuable to measure on a regular basis to inform decision-making at the practice and system (community, regional, provincial) levels? The votes were tabulated to generate separate ranked lists of practice- and system-level measurement priorities. The Summit proceedings can be found on CIHI's and HQO's websites (CIHI 2013; HQO 2013b). 
Following the Summit, the Steering Committee was broadened to include additional organizations representing primary care providers, hospitals, home and community care providers, patients and family caregivers. In Spring 2013, the organizations represented on the Steering Committee circulated a stakeholder survey to engage their members and solicit their views on the aspects of primary care performance that would be the most valuable to measure. Over 850 people responded. Informed by the Summit and survey results, the Steering Committee finalized the overarching PCPM framework (Figure 1).

\section{Developing specific measures for the PCPM framework} HQO, the Steering Committee, a Measures Working Group and a Technical Working Group collaborated to develop specific measures for the framework (Figure 2). The responsibilities of the three groups were:

- Steering Committee: Identify a set of measurement priorities for the PCPM framework based on the Summit and survey results.

- Measures Working Group: Select preferred measures for each measurement priority building on and guided by the criteria that were used during the Summit.

- Technical Working Group: Advise on technical specifications and infrastructure requirements for data extraction, analysis and reporting.

The Measures Working Group included primary care providers $(n=7)$, health system decision-makers $(n=5)$, patients and family caregivers $(n=3)$, patient relations professionals $(n=2)$, primary care researcher/clinicians $(n=2)$ and quality improvement specialists $(n=2)$. The Technical Working Group comprised primary care researcher/clinicians $(n=3)$ and data specialists from 10 organizations $(n=15)$.

\section{Results}

\section{Recommended measures}

In its Phase One Report, the Steering Committee selected specific measures for the measurement priorities in eight domains of the PCPM framework: access, integration, efficiency, effectiveness, focus on population health, safety, patient-centredness and appropriate resources (HQO 2014). Equity - the ninth domain - was identified as a cross-cutting domain that would be assessed based on a recommended set of 14 economic, demographic and social variables applied to the performance measures in the other domains.

At the system level, 48 (27\%) of the 179 recommended measures are currently available at the LHIN level and 90 measures (50\%) are available at the provincial level. Available system-level measures are derived from multiple sources, including the MOHLTC's Health Care Experience Survey (HCES), the Canadian Community Health Survey, the Commonwealth Fund International Health Policy Surveys and administrative data sets held by the ICES and CCO. The currency and frequency of reporting vary among the sources. 
FIGURE 1. The Primary Care Performance Management framework (Ontario Primary Care Performance Measurement Steering Committee 20 I4)

\begin{tabular}{|c|c|c|c|c|c|c|c|}
\hline Access & Integration & Efficiency & Effectiveness & $\begin{array}{l}\text { ocus on Population } \\
\text { ealth }\end{array}$ & Safety & Patient-Centredness & Appropriate Resources \\
\hline $\begin{array}{l}\text { Extent of (avoidable) } \\
\text { emergency department, } \\
\text { walk-in clinic, urgent care } \\
\text { centre use } \\
\text { *(Integration) } \mathbf{S} \\
\\
\text { Access to a regular } \\
\text { primary care provider S-P }\end{array}$ & $\begin{array}{l}\text { - Information sharing across } \\
\text { the continuum of care } \\
\text { including patients and family } \\
\text { caregivers } \mathbf{S + P} \\
\text { - Care coordination with other } \\
\text { health and community care } \\
\text { providers and services } \\
\text { *(Efficiency and Patient- } \\
\text { Centredness) SPP }\end{array}$ & $\begin{array}{l}\text { Per capita healthcare cost } \\
\text { (primary care, specialist } \\
\text { care, hospital care, } \\
\text { diagnostics, pharmaceuti- } \\
\text { cals, long-term care, } \\
\text { community care) SPP } \\
\text { - Support for family } \\
\text { caregivers } \mathbf{S P} \text {. } \\
\text { Unnecessary duplication of } \\
\text { diagnostic tests/imaging }\end{array}$ & $\begin{array}{l}\text { Management of chronic } \\
\text { conditions including people } \\
\text { with mental health and } \\
\text { addictions and multiple } \\
\text { chronic conditions GSP } \\
\text { Advanced } \\
\text { disease/palliative care } \\
\mathbf{s} \\
\text { Symptom management } \\
\text { *(Patient-Centredness) }\end{array}$ & $\begin{array}{l}\text { Preventive care for infants } \\
\text { and children (beyond } \\
\text { immunization) } \mathbf{S} \\
\\
\text { Health and socio- } \\
\text { demographic information } \\
\text { about the population } \\
\text { being served (including } \\
\text { health status) SPP } \\
\\
\text { Immunization through the } \\
\text { lifespan SPP }\end{array}$ & $\begin{array}{l}\text {-Infection prevention and } \\
\text { control } \mathbf{S} \\
\text { Medication management, } \\
\text { including medication } \\
\text { reconciliation } \mathbf{S P} \\
\\
\text { - Recognition and } \\
\text { management of adverse } \\
\text { events including medical } \\
\text { errors } \mathbf{S}: \mathbf{P}\end{array}$ & $\begin{array}{l}\text { Respect for patients' and } \\
\text { families' values, culture, } \\
\text { needs and goals } \mathbf{S P P} \\
\\
\text { - Process to obtain } \\
\text { patient/client and care- } \\
\text { giver input regarding } \\
\text { healthcare services } \\
\text { (S } \\
\\
\text { - Respectful and under- } \\
\text { standable communication }\end{array}$ & $\begin{array}{l}\text { Comprehensive scope of } \\
\text { primary care practice } \mathbf{S} \\
\text { Funds received by primary } \\
\text { care practices } \\
\text { (by category) } \\
\text { Human resources } \\
\text { availability, composition } \\
\text { (skills mix) and optimized } \\
\text { scope of practice } \mathbf{S} \\
\text { Healthy work environment } \\
\text { and safety } \mathbf{S}\end{array}$ \\
\hline $\begin{array}{l}\text { Timely access at regular } \\
\text { place of care } \mathbf{S}: \mathbf{P} \\
\text { Access to after-hours care } \\
\text { (telephone and in-person) } \\
\text { S-P }\end{array}$ & $\begin{array}{l}\text { ment with medical/surgical } \\
\text { specialist or other } \\
\text { specialized services } \\
\text { *(Access) G-P } \\
\\
\text { - Hospital admissions and } \\
\text { readmissions } \\
\text { *(Effectiveness) GPP }\end{array}$ & $\begin{array}{l}\text { Implementation and } \\
\text { meaningful use of } \\
\text { electronic medical } \\
\text { records/electronic } \\
\text { health records } \\
\star \text { (Integration) }\end{array}$ & $\begin{array}{l}\text {-Negotiated care plan for } \\
\text { patients with chronic } \\
\text { conditions } \\
\text { *(Patient-Centredness) } \\
\text { S:P }\end{array}$ & $\begin{array}{l}\text { Screening and manage- } \\
\text { ment of risk factors for } \\
\text { cardiovascular disease } \\
\text { and other chronic } \\
\text { conditions (e.g., obesity, } \\
\text { smoking, physical } \\
\text { inactivity, diet, alcohol and } \\
\text { substance abuse, socio- } \\
\text { demographic characteris- } \\
\text { stics, sexual and other high- }\end{array}$ & 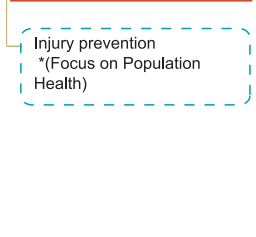 & $\begin{array}{l}\text { - Coordination of care } \\
\text { within the primary care } \\
\text { setting } \mathbf{S P P} \\
\\
\text { - Process for addressing } \\
\text { suggestions/complaints } \\
\text { S }\end{array}$ & $\begin{array}{l}\text { Funding and use of electronic } \\
\text { systems to link with other } \\
\text { settings * (Integration) } \\
\text { Practice improvement and } \\
\text { planning } \mathbf{s} \\
\text { - Human resources training } \\
\text { and professional develop- } \\
\text { ment, including patient-and } \\
\text { family-centred care } \$\end{array}$ \\
\hline $\begin{array}{l}\text { Access to non face-to-face } \\
\text { care (e.g., telephone, } \\
\text { e-mail, etc.) } \mathbf{S}-\mathbf{P} \\
\\
\text { Access to home visits for } \\
\text { target populations } \mathbf{S}-\mathbf{P}\end{array}$ & $\begin{array}{l}\text { primary care provider post } \\
\text { hospital discharge } \mathbf{S} \text { P } \\
\text { - Waiting time for community } \\
\text { services } \mathbf{S}-\mathbf{P}\end{array}$ & $\begin{array}{l}\text { and collaboration with } \\
\text { patients and families } \\
*(\text { aatient-Centredness and } \\
\text { Effectiveness) } \mathbf{S P} \text {. } \\
\\
\text { Patient wait times in office } \\
\text { P }\end{array}$ & $\begin{array}{l}\text { decision-making } \\
\star * \text { (Patient-Centredness) }\end{array}$ & $\begin{array}{l}\text { risk behaviours) } \\
\text { *(Effectiveness) } \\
\\
\text { Chrop } \\
\text { Chronic disease screening } \\
\text { (e.g.,cancer, diabetes, } \\
\text { hypertension, asthma, } \\
\text { depression, dementia) }\end{array}$ & & $\begin{array}{l}\text { Privacy and } \\
\text { confidentiality }\end{array}$ & $\begin{array}{l}\text { Provider remuneration } \\
\text { methods }\end{array}$ \\
\hline \multirow{2}{*}{$\begin{array}{l}\text { Patient access to their } \\
\text { own health information } \\
\text { * Efficieiency) }\end{array}$} & $\begin{array}{l}\text { Primary care providers' access } \\
\text { to specialist advice via } \\
\text { t telephone, e-mail, etc. }\end{array}$ & Extent of generic prescribing & & Prenatal care $\mathbf{S P}$ & & & $\begin{array}{l}\text { Availability of information } \\
\text { technology systems }\end{array}$ \\
\hline & $\begin{array}{l}\text { Time to referred diagnostic } \\
\text { I tests (e.g., CAT scan, MRI, } \\
\text { 'etc.. }\end{array}$ & & & & \multicolumn{2}{|c|}{\begin{tabular}{|l} 
Legend \\
$\qquad \begin{aligned} * & \text { Also relevant to mentioned domain } \\
\ldots \ldots . & =\text { Measurement area for future consideration } \\
\mathbf{S} & =\text { System level priority } \\
\mathbf{S} P & =\text { System and Practice level priority } \\
\mathbf{P} & =\text { Practice level priority }\end{aligned}$
\end{tabular}} & 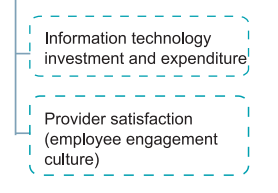 \\
\hline
\end{tabular}

Equity is a cross-cutting domain and will be assessed in relation to a variety of economic and social variables such as income, education, gender, disability, social support, mental health status, urban/rural location, age, sexual orientation/identity, language, immigration, ethno-cultural identity and Aboriginal status. 
FIGURE 2. Process to develop specific measures for the Primary Care Performance Measurement framework

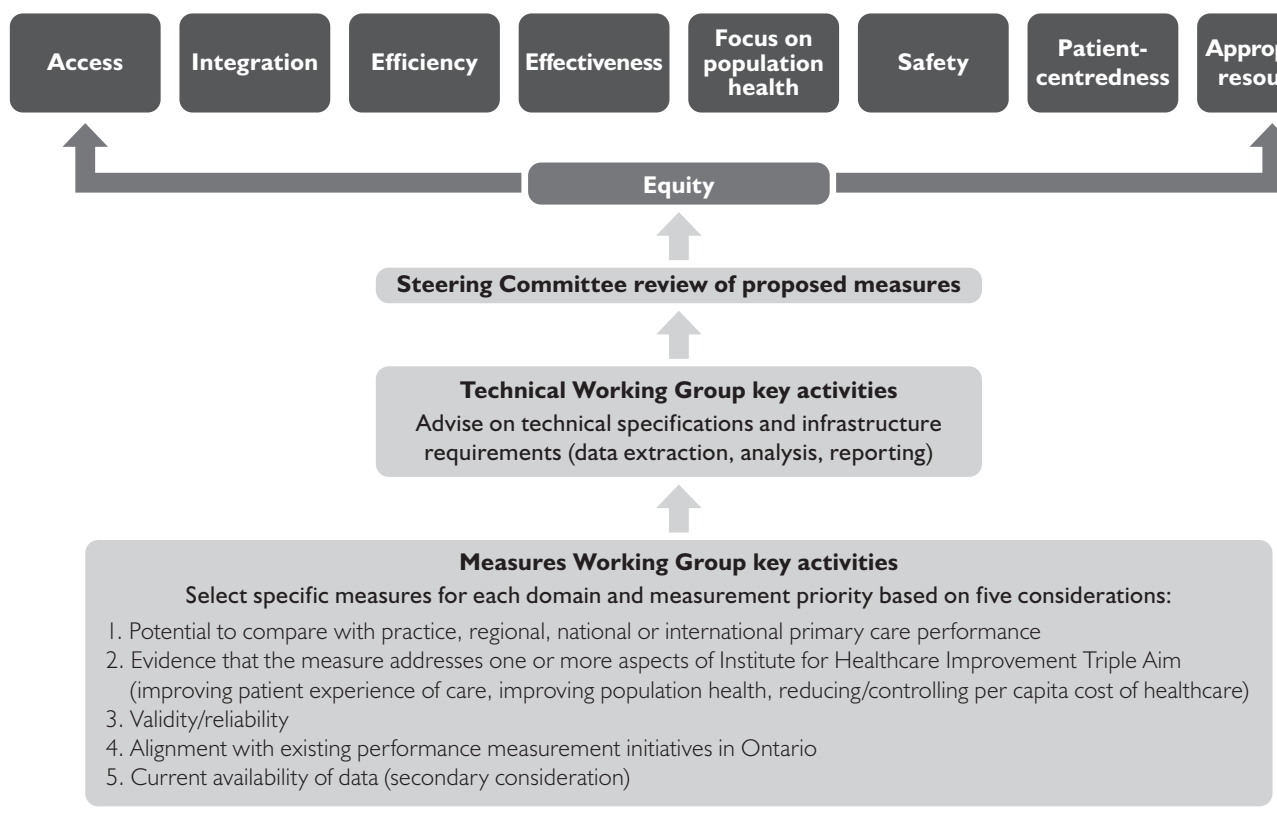

Advise on technical specifications and infrastructure requirements (data extraction, analysis, reporting)

\section{Measures Working Group key activities}

Select specific measures for each domain and measurement priority based on five considerations:

Potential to compare with practice, regional, national or international primary care performance

Evidence that the measure addresses one or more aspects of Institute for Healthcare Improvement Triple Aim

(

4. Alignment with existing performance measurement initiatives in Ontario

5. Current availability of data (secondary consideration)

Only 15 (13\%) of the 112 practice-level measures in the PCPM framework will be available in the near future to all primary care clinicians, mainly through the ICES-HQO Primary Care Practice Reports and CCO. Table 2 summarizes practice- and system-level measures by availability.

The recommended measures draw on multiple data sources. Administrative data held by the ICES, MOHLTC (Health Analytics Branch) and CCO could provide 23 practice-level measures (21\%) and 32 system-level measures (18\%). Electronic medical record data could generate 24 practice-level measures (21\%) and 13 system-level measures (7\%). A practice-level patient experience survey could provide 65 practice-level measures (58\%). Population survey data could produce 68 system-level measures (38\%). Provider reported that data could provide 47 system-level measures (26\%). Finally, primary care organization-reported data could be the basis for 19 system-level measures (11\%).

The technical details for each recommended measure, including measure name, description, definition and existing or potential data source, can be found in the Technical Appendices of the Steering Committee's Phase One Report.

\section{Recommendations for implementation}

To support the implementation of the PCPM framework, the Steering Committee made a series of recommendations that are outlined in Box 1 . 
TABLE 2. Summary of specific measures by availability

\begin{tabular}{|c|c|c|c|c|c|c|}
\hline \multirow[b]{2}{*}{$\begin{array}{l}\text { Domain } \\
\text { Practice and } \\
\text { system levels* }\end{array}$} & \multicolumn{6}{|c|}{ Number of measures } \\
\hline & $\begin{array}{l}\text { Currently } \\
\text { reported }\end{array}$ & $\begin{array}{l}\text { Currently } \\
\text { reported } \\
\text { but modified } \\
\text { wording } \\
\text { recommended }\end{array}$ & $\begin{array}{l}\text { Not currently } \\
\text { available } \\
\text { but could } \\
\text { be reported } \\
\text { using existing } \\
\text { infrastructure }^{\S}\end{array}$ & $\begin{array}{l}\text { Not currently } \\
\text { available but included } \\
\text { in survey tool under } \\
\text { development; } \\
\text { infrastructure } \\
\text { required for data } \\
\text { collection, analysis } \\
\text { and reporting" }\end{array}$ & $\begin{array}{l}\text { Measures } \\
\text { not currently } \\
\text { available; new } \\
\text { infrastructure } \\
\text { required for } \\
\text { data collection, } \\
\text { analysis and } \\
\text { reporting }\end{array}$ & Total \\
\hline Access & 8 & 3 & 1 & 0 & 12 & 24 \\
\hline $\begin{array}{l}\text { Patient- } \\
\text { centredness }\end{array}$ & 2 & 2 & 12 & 9 & 12 & 37 \\
\hline Integration & 15 & 2 & 3 & 1 & 11 & 32 \\
\hline Effectiveness & 15 & I & 16 & 1 & 43 & 76 \\
\hline $\begin{array}{l}\text { Focus on } \\
\text { population health }\end{array}$ & 24 & 4 & 4 & 1 & 14 & 47 \\
\hline Efficiency & 7 & I & 8 & 0 & 7 & 23 \\
\hline Safety & 3 & 3 & 3 & 0 & 14 & 23 \\
\hline $\begin{array}{l}\text { Appropriate } \\
\text { resources }\end{array}$ & 14 & 1 & 0 & 0 & 14 & 29 \\
\hline Total & 88 & 17 & 47 & 12 & 127 & 291 \\
\hline Equity & $\begin{array}{l}\text { Cross-cutting } \\
\text { ethno-cultura } \\
\text { aboriginal stat }\end{array}$ & $\begin{array}{l}\text { omain - Analysis w } \\
\text { dentity, disability, so } \\
\text {, employment statı }\end{array}$ & $\begin{array}{l}\text { e based on } 14 \text { por } \\
\text { I support, income, } \\
\text { and mental health s }\end{array}$ & $\begin{array}{l}\text { ation characteristics: age, } \\
\text { ucation, sexual orientation } \\
\text { us }\end{array}$ & $\begin{array}{l}\text { der/sex, urban/rural I } \\
\text { entity, language, immi }\end{array}$ & $\begin{array}{l}\text { ation, } \\
\text { ation, }\end{array}$ \\
\hline
\end{tabular}

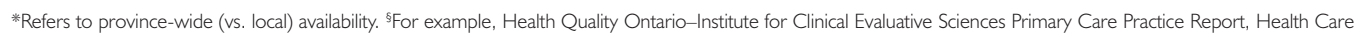
Experience Survey; "Health Quality Ontario Primary Care Patient Experience Survey.

${ }^{\dagger}$ For example, electronic medical record-based measures.

BOX 1. Recommendations of the Steering Committee to support the transition to better primary care performance measurement

- Accelerate efforts to strengthen vendor requirements to incorporate standardized high-value data elements; facilitate standardized data capture, data transfer and exchange; and simplify processes for extracting and analyzing data.

- Develop the necessary infrastructure to make the measures available throughout the province at both the practice and system levels, including: (I) a practice-level patient experience survey and a mechanism for pooling EMR data to provide regular feedback to practices over time and allow for comparison with peers; (2) a mechanism for collecting data from primary care providers and organizations; and (3) a mechanism for combining primary care performance measures from multiple sources.

- Develop aggregate measures of primary care performance that reflect performance at a broad domain level (e.g., effectiveness), for a more limited area of practice (e.g., management of chronic conditions) or based on a framework such as the IHl's Triple Aim.

- Identify organizational responsibility for producing coherent, user-friendly reports using performance measurement data.

- Include the PCPM framework measures in new survey tools or updates of existing ones.

- Equip primary care providers, organizations, health system managers and policy makers with an understanding of performance measurement, quality improvement methods and leading practices.

- Update and revise the PCPM framework, as required, to align with emerging evidence, changing policy priorities, new data sources and evolving information needs, using structures and processes that are inclusive of stakeholders, including patients, caregivers and the public.

- Commission an arm's-length formative evaluation of the implementation of the PCPM framework to detect and address implementation challenges and to identify and build on implementation successes. 
As a next step, the Steering Committee committed to selecting two priority subsets of measures and recommended approaches for data collection to support immediate measurement at both the system and practice levels.

\section{Discussion}

\section{Lessons learned}

Other jurisdictions developing systems for monitoring and reporting on primary care performance can benefit from the lessons learned in Ontario related to stakeholder and patient engagement and resources requirements. Stakeholder engagement has been a key success factor in this initiative. Stakeholder ownership of the recommendations is an important driver of uptake, implementation, sustainability and, ultimately, quality improvements. The collaboration among stakeholders representing patients, providers, data holders, researchers, managers, policy makers and funders from across Ontario has supported alignment and a high degree of consensus on the specific measures that constitute the framework.

Tapping into the experience and expertise of patients and family caregivers through their participation on the Steering Committee and in the Measures Working Group greatly enhanced the meaningfulness and potential value of the recommended PCPM measures. We learned early in the process that the perspectives of primary care providers, managers and policy makers are not always consistent with those of patients and their families. A key to success was the comfort and ability of the patient and family caregiver participants to express themselves freely during the measures selection process. The effect of the partnership with patient and family caregivers is evident from the number of selected measures that are patient-reported - 66 at the system level and 64 at the practice level out of the 199 measures in the framework. In addition, new measures were created and survey-based measures were substantially reworded to reflect the concerns, needs and values of patients and caregivers. Based on this experience, we strongly recommend extensive participation by patients and family caregivers throughout initiatives of this type.

Engagement and consensus-building among a broad range of stakeholders are timeconsuming and resource-intensive. The Steering Committee guiding the work met over 20 times, for an average of 4 hours per meeting. The Measures and Technical Working Groups met eight times, each for an average of 4 hours per meeting. Representation included 22 people on the Steering Committee, 21 people on the Measures Working Group and 18 people of the Technical Working Group. The HQO team supporting the work included four dedicated staff and a Senior Advisor who invested, on average, $60 \%$ of their time throughout the course of two years with supervision from a senior leadership team. This level of commitment was only possible because the partners in this initiative shared a conviction that a systematic approach to performance measurement and feedback is an essential underpinning for practice- and system-level healthcare improvement.

Not all of the organizations represented on the Steering Committee had collaborated before. However, after working together over a period of two-and-a-half years, the Steering Committee achieved a high level of trust and mutual respect. 
The Steering Committee was the final decision-maker in the process with the HQO providing secretariat support. This arrangement helped to build stakeholders' sense of ownership and commitment to implementation of the recommendations.

\section{How could the measures be used?}

The recommended PCPM measures were identified through a rigorous and inclusive stakeholder engagement process that was designed to identify performance measures that are valuable for decision-making. Alignment of the PCPM initiative with existing performance measurement and quality-improvement initiatives in Ontario was considered during the framework's development and was facilitated by representation on the Steering Committee and Working Groups of organizations that are leading many of those initiatives.

The recommended set of measures provides a menu of primary care performance measures for use at the system and practice levels. Clinicians, primary care organizations, system managers, policy makers, funders, researchers and organizations representing patients and the public can draw on this bank of recommended measures to meet their diverse needs. The measures can help primary care practices to identify opportunities for improvement and clinicians to evaluate and explore aspects of their performance as part of reflective learning activities. Health system managers, policy makers and funders could use the measures to monitor system performance and the effect of policy initiatives and health system investments. Planners and decision-makers could use the measures to conduct population needs-based planning. Evaluators could use the measures to assess the implementation and effects of innovative primary care programs. Researchers could select outcome measures for use in clinical, health services and policy research in primary care. The measures could help patient-advocacy and civil-society organizations gauge the responsiveness of primary care to the needs and expectations of patients, family caregivers and the public. For some measures, data will be available from existing reports or data sources. In other cases, users would need to collect data themselves.

\section{Data gaps}

Our process identified major gaps in data availability at both the practice and system levels. At the system level, important gaps exist for mental health, health promotion, maternal health, family and caregiver experience, comprehensiveness of care and healthcare provider experience. In the short term, data availability could be enhanced by adding additional high-priority measures to the HCES and expanding the number of measures derived from administrative databases held at ICES. At the practice level, key data gaps include mental health and safety. Standardized EMR specifications that facilitate the extraction, pooling, analysis and reporting of EMR data are critically required to improve the availability of high-value practice-level measures.

\section{Relationship to other frameworks}

The Ontario PCPM framework differs from other conceptual and measurement frameworks for primary care in a number of respects. Most other frameworks aim to be generic, 
whereas ours is intended to be specific to the current and short-term-future context of Ontario. Our framework makes a distinction between measures that are applicable at the practice/organizational level and those that are relevant to performance measurement at the system level. Our process was driven by stakeholder perceptions of what would be useful to measure, whereas most other frameworks have been expert-driven. The Ontario framework is populated by a large number and wide diversity of specific measures, reflecting the multiple perspectives represented in the development process. Because this initiative was focused on performance, our framework and specific measures emphasize outcomes of care, processes of care linked in evidence and logic to health outcomes and patients' experience rather than structural and organizational characteristics that figure more prominently in other frameworks.

An initiative is underway in Alberta to develop common quality and outcome measures for the province's Primary Care Networks (PCNs) (Oddie and Krajnak n.d., Scott Oddie personal communication, February 26, 2014). The participants include 25 executive directors, evaluators and provider leads from $13 \mathrm{PCNs}$ and representatives from Alberta Health, Alberta Health Services, Health Quality Council of Alberta, CIHI and academic institutions. Their proposed minimum data set for PCNs includes measures related to access, health promotion, early detection and disease prevention, chronic disease management, patient experience, interdisciplinary teams, cost of services and safety, all of which are included in the PCPM set of measures.

\section{Conclusion}

Systematic, regular and relevant performance measurement is essential to identify opportunities for - and the impact of - improvement efforts. A process that is inclusive of key stakeholders can help to ensure the development of a framework that meets the needs of stakeholders and maximizes their commitment to its application to support improvements in policy and practice.

Given the context-specific and stakeholder-driven nature of this initiative, our framework and specific performance measures cannot be generalized to other times and places. However, our methods are transferable and the suite of measures that were selected and technically specified may be a useful source of potential measures for use in other settings. Our process was time- and resource-intensive, in part because of the size and complexity of Ontario's healthcare system, and may need to be streamlined in settings where fewer resources are available. If properly aligned, similar processes in other provinces can build a coordinated and sustainable approach to measure primary care performance in Canada. Given the primitive state of routine PCPM in Canada, particular attention needs to be given to the identification of data gaps and the development of processes for collecting and analyzing data to fill those gaps.

Correspondence may be directed to: Wissam Haj-Ali, Health Quality Ontario, 130 Bloor Street West, 10 fl floor, Toronto, ON M5S 1N5; e-mail:wissam.haj.ali@mail.utoronto.ca. 


\section{References}

Accreditation Canada. n.d. "Primary Care Services for Standalone Clinics." Accreditation Canada. Retrieved September 15, 2016. <https://accreditation.ca/primary-care-services-standalone-clinics>.

Aggarwal, M. and B. Hutchison for the Canadian Working Group for Primary Healthcare Improvement. 2012. Toward a Primary Care Strategy for Canada. Ottawa, ON: Canadian Foundation for Healthcare Improvement. Canadian Institute for Health Information (CIHI). 2012. Pan-Canadian Primary Health Care Indicator Update Report. Ottawa, ON: Author.

Canadian Institute for Health Information (CIHI). 2013. Ontario Primary Care Performance Measurement Summit Proceedings Report. Ottawa, ON: Author.

Canadian Institute for Health Information (CIHI). 2015. How Canada Compares: Results from the Commonwealth Fund 2014 International Health Policy Survey of Older Adults. Ottawa, ON: Author.

Canadian Institute for Health Information (CIHI). 2016. How Canada Compares: Results from the Commonwealth Fund 2015 International Health Policy Survey of Primary Care Physicians. Ottawa, ON: Author.

Haggerty, J. and C. Martin. 2005. Evaluating Primary Care in Canada: The Right Questions to Ask! Ottawa, ON: Health Canada. Retrieved September 15, 2016. <www.apps.hc-sc.gc.ca/hcs-sss/phctf-fassp.nsf/WebProject/00 69? OpenDocument\&lang=eng\&>.

Haggerty, J., F. Burge, J. Levesque, D. Gass, R. Pineault, M. Beaulieu et al. 2007. "Operational Definitions of Attributes of Primary Health Care: Consensus among Canadian Experts." Annals of Family Medicine 5(4): 336-44.

Health Quality Ontario (HQO). 2013a. Primary Care Performance Measurement Environmental Scan. Toronto, ON: Author. Retrieved January 15, 2016. <www.hqontario.ca/research/PCPM_Matrix.xlsx>.

Health Quality Ontario (HQO). 2013b. Ontario Primary Care Performance Measurement Summit: Proceedings Report. Toronto, ON: Author. Retrieved January 15, 2016. <www.hqontario.ca/Portals/0/Documents/pr/ pc-summit-proceedings-report-en.pdf>.

Health Quality Ontario. 2014. A Primary Care Performance Measurement Framework for Ontario; Report of the Steering Committee for the Ontario Primary Care Performance Measurement Initiative: Phase One, 2014. Retrieved September 15, 2016. <http://www.hqontario.ca/portals/0/Documents/pr/pc-performance-measurement-report-en.pdf>.

Hogg, W., M. Rowan, G. Russell, R. Geneau and L. Muldoon. 2008. “Framework for Primary Care Organizations: The Importance of the Structural Domain." International Journal for Quality in Health Care 20(5): 308-13.

Hutchison, B., J.F. Levesque, E. Strumpf and N. Coyle. 2011. "Primary Health Care in Canada: Systems in Motion." Milbank Quarterly 89(2): 256-88.

Hutchison, B. 2013. "Reforming Canadian Primary Care - Don't Stop Half-Way." Healthcare Policy 9(1): 12-24.

Hutchison, B. and R. Glazier. 2013. “Ontario’s Primary Care Reforms Have Transformed the Local Care Landscape, but a Plan is Needed for Ongoing Improvement." Health Affairs 32(4): 695-703.

Hutchison, B. 2014. "The Evolution of Primary Care in Canada: Diverse Approaches, Uneven Progress, Continuing Challenges” (presentation). Colloque Jean-Yves Rivard, Université de Montréal.

Institute for Healthcare Improvement (IHI). n.d. "IHI Triple Aim Initiative." Retrieved October 13, 2016. $<$ www.ihi.org/engage/initiatives/tripleaim/pages/default.aspx >.

Institute of Medicine (IOM). 2001. Crossing the Quality Chasm: A New Health System for the 21st Century. Washington, DC: National Academies Press.

Kates N., B. Hutchison, P. O’Brien, B. Fraser, S. Wheeler and C. Chapman. 2012. "Framework for Advancing Improvement in Primary Care." Healthcare Papers 12(2): 8-21.

Lavis, J.N. 2010. Issue Brief: Supporting Quality Improvement in Primary Healthcare in Ontario. Hamilton, ON: McMaster Health Forum. Retrieved September 15, 2016. <http://digitalcommons.mcmaster.ca/ mhf_issue-briefs/6/>.

Levesque, J.F., J. Haggerty, F. Burge, M.D. Beaulieu, D. Gass, R. Pineault et al. 2011. “Canadian Experts' Views on the Importance of Attributes within Professional and Community-Oriented Primary Healthcare Models." Healthcare Policy $7($ Sp.): 21-30. 
Establishing a Primary Care Performance Measurement Framework for Ontario

Marchildon, G.P. and B. Hutchison. 2016. "Primary Care in Ontario: New Proposals after 15 Years of Reform." Health Policy 120: 732-38.

Oddie, S. and J. Krajnak. n.d. "PCN Measurement Capacity Initiative." Red Deer, AB: Red Deer College. Retrieved September 15, 2016. <http://rdc.ab.ca/about/research-innovation/applied-research-innovation/ health-research-collaborative/pcn-measurement-capacity-initiative>.

Ontario Ministry of Health and Long-Term Care (MOHLTC). 2011. Strategic Directions for Strengthening Primary Care in Ontario: Overview of Process and Recommendations of the Primary Healthcare Planning Group. Toronto, ON: Author. Retrieved January 15, 2016. <http://www.google.ca/url?sa=t\&\&rct=j\&q $=\&$ esrc $=\mathrm{s} \&$ source $=w e b \& c d=2 \& v e d=0 \mathrm{CCUQFjAB} \& u r l=h t t p \% 3 \mathrm{~A} \% 2 \mathrm{~F} \% 2 \mathrm{Fwww} \cdot$ trilliumresearchday. com\%2Fdocuments\%2F2012_PHPG_Overview\%2520of\%2520Process\%2520and\%2520Recommen dations_Final.pdf\&ei=_fmqU9qxJoiZyAT7voLIDQ\&usg=AFQjCNGpRXqP9Pt_gODzCdgjck1_ F9Br3w\&bvm=bv.69620078,d.aWw>.

Osborn, R., D. Moulds, D. Squires, M.M. Doty and C. Anderson. 2014. "International Survey of Older Adults Finds Shortcomings in Access, Coordination, and Patient-Centered Care." Health Affairs 33(12): 2247-55.

Osborn, R., D. Moulds, E.C. Schneider, M.M. Doty, D. Squires and D.O. Sarnak. 2015. "Primary Care Physicians in Ten Countries Report Challenges in Caring for Patients with Complex Health Needs." Health Affairs 34(12): 2104-12.

Strumpf, E., J.F. Levesque, N. Coyle, B. Hutchison, M. Barnes and R.J. Wedel. 2012. "Innovative and Diverse Strategies toward Primary Health Care Reform: Lessons Learned from the Canadian Experience." Journal of the American Board of Family Medicine 25(Suppl. 1): S27-S33.

Watson, D., A.M. Broemeling, R.J. Reid and C. Black. 2004. "A Results-Based Logic Model for Primary Health Care: Laying an Evidence-Based Foundation to Guide Performance Measurement, Monitoring and Evaluation." Healthcare Policy 5(Sp.): 33-46.

\title{
Join the conversation
}

@longwoodsnotes

\author{
YouTube youtube.com/LongwoodsTV
}

(2) pinterest.com/longwoods

facebook.com/LongwoodsPublishingCorporation 